\title{
TAŞINMAZ SATIMINDA VEKALET
}

\author{
Dr. Veysel BAŞPINAR*
}

\section{Genel Olarak Taşınmaz Satım Sözleş̧mesi}

Borçlar Kanununda satım ve trampanın yer aldığt altıncı Bab'ın üçüncü Faslında taşınmaz satımı düzenlenmiştir. Bu fasıl içinde yer alan BK.m. 184 ile MK.m. 632, 911 ve Tapu Sicili Tüzügü'nün' ${ }^{1}$ 7. maddesinden hareketle taşınmaz satımının konusu tesbit etmek mümkündür. Söz konusu hükümlere göre taşınmaz mülkiyetinin konusunu; tapu küttïgüne taşınmaz olarak kaydedilen nesneler ve haklar oluşturur ${ }^{2}$. Buna göre taşınmaz kavramı; yerine sabit olan arazi, bina, orman gibi özüne bir zarar gelmeden bir yerden başka bir yere nakli mümkün olmayan şeylerle, tapu sicilinde bağımsız ve sürekli olmak üzere ayn bir sahifeye kaydedilen haklar ${ }^{3}$ ve Kat

* A.Ũ. Hukuk Fakültesi Medeni Hukuk Anabilim Dalı Araştırma Görevlisi

1. Bkz. 18.5.1994, 94/5623 (Resmâ Gazete, 7.6.1994, 21953). Söz konusu maddeye göre, tapu siciline taşınmaz mal ye hak olarak arazi, bağımsız bölìmler ve müstakil ve daimi haklar yazilır.

2. Eşya, çeşitli ayrimlara tâbi tutulmaktadır. Bu aynmlardan biri de, eşyanın taşını olup olmamasına göre yapımaktadur. Buna göre eşya, taşıır eşya ve taşımaz eşya olarak ikiye ayrılır. Gerçek anlamda taşınmaz eşya arazidir. Buna karşıłık, hukuk sistemleri, taşınmaz kavramına gerçek anlamından cok ayrı ve teknik bir anlam yitklemişlerdir. Gerçekten de, hukuk anlaminda taşınmaz kavramı, arazi yannda tapu kütüugüinün ayn bir sahifesipe kaydedilen bağımsız ve sürekli aynû haklan, madenleri, kat mîtkiyetinde bağımsız bölümleri de kapsar. Bu konuda geniş bitgi için bkz. Lötscher, Markus, Das Grundstúck als Gegenstand von Grundstijckpfandrechten, Freiburg/Schweiz 1988, sh. 5 vd; Unal, Mehmet; Şeklî Eşya Hukuku, 2. Bası, Ankara 1994, sh. 22; Araf, Fahrentin; Borçlar Hukuku Ozel Borç Ilişkileri, Ankara 1997, sh. 21, 96 vd. Icra ve İflâs Kanununa (m.23/IV ve 136) göre, niteliği ițibariyle taşınır olan gemiler taşınmaz kabul edilmiştir. TTK. m. 839 vd nda, gemiler hakkında taşınmaza benzemekle birlikte özel bir rejim öngörülmüş̧ür. Gemi, fizikî yapısı itibariyle taşınır eşyadır. Bu husus geminin tanımını yaparken hareket kaabijiyetinden söz eden TTK. m. 816'da açıkça yer almaktadır. Ancak, ekonomik hayatta oynadığı önemli rol neđleniyle gemi hakkında, aynî haklarla itgili çeşitli konularda taşınır - mallardan farkiı hakikúmler öngörülimüştuirr. Bu konuda geniş bilgi için bkz. Kalpsüz, Turgut; Deniz Tiçareti Hukuku,C.l, Giriş-Gemi, Ankara 1971, sh. 263-264.

3. Soz konusu haklar, bir taşınmaz üzerinde kurulan bał̆ımsız ve sürekli nitelik taşıyan ist (yapı) hakkı ve kaynak hakkı gibi hakJardır. Bu konuda geniş bilgi için bkz. Lötscher, sh. 13 vd; Unal, Esya, sh. 22; Ayn Yazar; Türk Medeni Hukukunda Yapı (Ust) Hakkı, Ankarz 1988, sh. 1 vd; Gürsoy, K.T/Eren, F/Cansel, E.; Türk Esya 
Mülkiyeti Kanunu'na göre kat mülkiyeti kütüğünde ayrı bir sahifeye kaydedilen bağımsız bölümlerdir ${ }^{4}$. MK.m 634 ve BK.m.213'e göre, bu anlamdaki taşınmazlar üzerindeki mülkiyet hakkını nakleden sözleşmelerin resmi şekilde yapılması gerekir. Söz konusu maddeler temel bir ilkeyi öngörmektedirler. Bu ilkeye göre, taşınmaz mülkiyetini devir borcunu doğuran sözleşmelerin resmi şekilde yapılması gerekirs

Medeni Kanun ve Borçlar Kanununun ilgili hüküimleri taşınmaz satımı için resmi şekil öngörmekle ${ }^{6}$ beraber bu sözleşmeye resmiyet kazandıracak makamı belirtmiş değildir. Bu konudaki hükümler Tapu Kanununda yer almaktadır. Gerçekten de, TK.m.26'ya göre, taşınmaz mülkiyetini nakleden sözleşmelere resmiyet kazandıracak makam; tapu sicil muhafızlan veya memurlarıdır. Buna karşılık, 1984 yılında kabul edilen 3045 sayılı kanuna göre, taşınmaz satımı sözleşmesine resmiyet kazandıracak makam tapu müdürlïğgudür'.

\section{Taşınmaz Satımında Vekâlet ve Şekli}

\section{A. Genel Olarak}

Taşınmaz alım-satımının bizzat alıcı veya satıcı tarafından değil de, bunlarnn tayin edecekleri bit vekil aracılığı ile de yapılması mümkündür. Acaba bu konuda verilecek vekâlet taşınmaz satım sözleşmesi gibi resmi şekle tâbi midir? Bu soruya doktrinde ve uygulamada farkh cevaplar verilmiştir. Bunun nedeni; taşınmaz satı$\mathrm{m} ı$ için düzenlenen vekâletnamenin şekli hakkında Medeni Kanun

Hukuku, 2. Baskı, Ankara 1984, sh 470 vd; Oğuzman, K./Seliçi, Ö.; Eşya Hukuku, 7. Bası, İstanbul 1997, sh. 277-278; Sirmen, Lẩle; Esya Hukuku, Ankara 1995, sh. 9 vd; Tandoğan, Halûk; Borçlar Hukuku Özel Borç Ílişkileri, C. V/1, 3. Bası, Ankara 1984, sh. 221 vd.; Yavuz, Cevdet; Türk Borçlar Hukuku Özel Hükümler 4. Baskı, Istanbul 1996, sh. 173.

4. Geniş bilgi için bkz. Unal, Eşya, sh. 23; Lötscher, sh. $20 \mathrm{vd;} \mathrm{Gïrsoy/Eren/Cansel,}$ sh. 373 vd; Oğuzman/Seliçi, sh. 277.

5. Oğuzman/Seliçi, sh. 343; Gürsoy/Eren/Cansel, sh. 480; Eren, Fikret: Borçlar Hukuku Genel Hükümler, C. I, 5 . Bası, İstanbul 1994, sh. 348; Tandoğan, I/1, sh. 217 vd: Yavuz. Borçlar, sh. 175; Aral, sh. 96-97; Y.15. HD. T. 17.2.1983, E. 1983/206, K.1983/269 (YKD. 1983, S.5. sh. 745); Y. 13. HD. T. 24.12.1984, E.1984/6592. K.1984/618) (YKD. 1985, S.2, sh. 248-250).

6. Hukukî işlemler için Medeni Kanun ve Borçlar Kanununda öngörün hïkümlerde şekil, geçerlik şart olarak kabul edilmiştir. But tür hijkimlere misal olarak MK. m. $173,256,291,492,634$; BK. m. 163, 213, 238/I, 404, 484 gösterilebilir. Bu konuda geniş bilgi için bkz. Altaş, Hüseyin; Şekle Aykınlığın Olumsuz Sonuçlannın Düzeltilmesi, Ankara 1998, sh. 70 vd.

7. Bu konuda geniş bilgi için bkz. Simmen, sh. 293; Aral, sh. 97. 
ve Borçlar kanununda bir hüküm bulunmamasıdır ${ }^{8}$. Borçlar Kanununun temsil ile ilgili hükümlerinde de bu konuda bir kural yer almış değildir. Konuyla ilgili olan BK.m. 388/III'de yer alan "hususi bir salâhiyeti haiz olmadıkça vekil,... bir gaynmenkulü temlik veya aynî bir hak ile takyit edemez" hükmü; vekâletin şekline değil, kapsamına ilişkin bir hüküm olup, bu konuda genel bir temsil ${ }^{7}$ yetkisinin yeterli olmadığını ortaya koymak için öngörülmüştür ${ }^{10}$.

5.5.1972'de yürürlüğe giren 1512 sayılı Noterlik kanunu (NK) m. 89'a göre tapu da işlem yapılmasıṇı gerektiren sözleşme ve vekâletnamelerin düzenleme şeklinde yapılması gerekir. Söz konusu hükümle BK.m.11'in yürürlükten kaldınlıp kaldırılmadığı doktrinde tartışmalırıdır. Bu tartışmalar, vekâletin geçerlik ve isbat açısından şekle bağlı olup olmamasına göre, iki konu da cereyan etmektedir.".

\section{B. Geçerlik Açısından:}

BK.m.11, sözleşmelerin şekli ile ilgili olarak genel bir kural getirmiştir. Buna göre, kanunda açıça yer almadıkça sözleşmenin geçerliği hiçbir şekle tâbi değildir. Taşınmaz satımı için verilecek vekâletin şekli konusunda MK.m.634 ve BK.m.213'de bir hüküm mevcut değildir. Bu kuraldan hareketle ve kanunun lâfzına bağlı kalarak yapılacak bir yorumla taşınmaz alımı veya satımı için verilen vekâletin şekle tâbi olmadiğnı iddia etmek mümkündür. Tabî̀ ki, taraflar aralannda anlaşarak vekâlet için adî yazılı ya da resmi şekil şartı öngörebilirler. Böyle bir vekâletin geçerlik açısından şekli tâbi olup olmadığı doktrinde tartışmalıdır:

Bir görüşe göre ${ }^{12}$, taşınmaz satımı için verilen vekâletin resmî şekilde yapılması gerekir. Burada vekâlet için öngörülen şekil şartı, geçerlik şartı olup, bunun noter tarafından re'sen düzenlenmesi ge-

8. Feyzioğlu, F. Necmettin; Bonçlar Hukuku Hususî Kısım Akdin Muhtelif Nevileri, C. I, 4. Bası, Istanbul 1980, sh. 95-96.

9. Genel temsil-özel temsil ayrum ve şartlan konusunda geniş bilgi için bkz. Yılmaz, Ejder: Genel Vekaletname-Özel Vekaletname Ayurm, TNBHD, S.86 (1995), sh. 12 vd. BGE 99 II 43; ZBJV 1 11, sh. 92 vd.

10. Feyzioğlu, 96. Ayrtca bkz. Furler, Elly; Auftrag, SJK. Nr. 327.

11. Aynı yönde görüiş için bkz. Feyzioğlu, sh. 96; Tandoğan I/1, sh. 242 vd.

12. Oğuzman/Seliçi, sh. 291; Oğuzman, M. Kemal; Gayrımenkule Müteallik Vekâlet ve Namt Müstearla Muamele Idddialarnnın Ispat Sekli Hakkonda Temyiz Mahkemesinin Yeni Içtihad, Medeni Hukuk Pratik Çalışmaları III, 2. Bası, Istanbul 1984, sh. 39 vd. 
rekir. Bu görüşü savunan yazarlata göre ${ }^{13}$, BK.m.1 l'de taşınmaz satımı için verilecek vekâlet konusunda bir hüküm bulunmadığını dikkate alarak söz konusu vekâletin hiçbir şekle tâbi olmadığını ileri sürmek kanunun lâfzına uygundur. Borçlar Kanununun temsili düzenleyen hükümlerinde de durum pek farklı değildir. Ancak, şekil konusundaki hükümlerin amacı ve kanunun ruhu bakımından aynı sonuca varmak mümkün değildir. Çünkü taşınmaz satım sözleşmesi geçerlik açısından şekle tâbidir. Esas sözleşme yani, taşınmaz satım sözleşmesinin resmî şekle tâbi olduğu bir yerde vekâletin de resmî şekilde yapılması gerekir. Zira, vekâlet asıı sözleşmeyi yapmak için gerekli olan temsil yetkisi ve vekil olmayı kapsar. Aksi halde temel ilişkinin geçersiz olması nedeniyle taşınmaz satımı da geçersiz olur ve tapudaki kayıt yolsuz bir kayıt niteliği taşır. Vekâletin resmî şekle tâbi olmaması kanunun, şekil kurah ile taraflan koruma amacı ile de bağdaşmaz ${ }^{14}$. Çünkü, kanun koyucunun buradaki amacı temsil yetkisi vereni, yani taşımaz malikini düşünmeye sevketmek, iktisap sebeplerinde mümkün olduğu kadar güveni koruyan bir durum sağlamaktır' ${ }^{15}$. Özellikle şekil kuralı sayesinde tapu siciline yapılan tescil işlemi için sağlam ve güvenilir bir dayanak elde edilmiş olur ${ }^{16}$. Zira, taşınmaz satımında aranan resmî şeklin (BK.m.213) tarafları düşünmeye sevketmek ${ }^{17}$ olarak ifade edilen rolünün burada söz konusu oldugu iddiası da doğru değildir. Ayrıca, BK.m.396'daki sözleşmeden tek taraflı rücu, azil ve istifa imkânı fazla büyüttülmemelidir. Zira, bu imkân vekilin taşınmaz alım-satımını yaptığı ana kadar önem arzeder. Şayet alım-satım gerçekleşmişse, azil ve istifa buna engel olamaz $z^{18}$. Ayrıca vekil, taşınmazı kendi nam ve müvekkili hesabına satın aldığı takdirde, müvekkil vekili azletse bile, onun yaptığı masraflan, öncelikle taşınmazın bedelini satıcıya ödemek, vekili borçlarından kurtarmak zorundadır (BK.m.394, 396). Rücunun burada, müvekkile bir faydası olmamaktadır ${ }^{19}$. Zira, vekili satım sözleşmesini yaptıktan sonira azletmenin hiçbir faydası yoktur. Yapılan satım sözleşmesine bağlı

13. Oğuzman/Seliçi, sh. 291; Oğuzman, sh. 39; Kocayusufpaşaoğlu, Necip; Türk Medeni Hukukunda Gayrimenkul Satus Vaadi, İstanbul 1959, sh. 105.

14. Kocayusufpaşaoğlu, Vaad, sh. 105.

15. Oğuzman/Seliçi, sh. 290 .

16. YîK. T. 30.9 .1988 , E. 1987/2, K. 1988/2 (Şener, Eșat: Tüm Yargıtay İçtihadı Birlestirme Kararlari, Ankara 1997, sh. 806-816)

17. Bkz. Tư̆g, Adnan; Türk Özel Hukukunda Sekil, 2. Bası, Konya 1994, sh. 64; Eren, sh. 288; Inan, Ali Naim; Borçlar Hukuku Genel Hükúmler, 3. Baskı, Ankara 1984, sh. 130; Arsebuk, A. Esat; Borçlar Hukuku, C. I-II, 3. Baskı, Ankara 1950, sh. 470 not. 26 .

18. Oguzman, sh. 40-41.

19. Oguzman, sh. 41. 
olan (BK.m.32/) satıcı, tescili yaptrrmaya mecburdur (MK.m.642). O halde şeklin faydası olarak gösterilen "taraflan düşünmeye sevketmek", dolayısıyla onları koruma amacı kendisini burada da hissettirir. Kaldı ki, taşınmaz satımında resmi şeklin amacr; sadece tarafları düşünmeye sevketmek değildir ${ }^{20}$. Kanunkoyucu böyle bir sonucu kabul etseydi vekâlet sözleşmesini, kefalet sözleşmesinde olduğu gibi, yazılı şekle tâbi tutmakla yetinebilirdi. $O$ halde taşınmaz satımının resmî şekle tâbi tutulmasının sebebini başka alanlarda aramak gerekir"

Resmî şekil, borçlandırıcı işleme, mümküin olduğu kadar sahih bir durum sağlamak, tapu siciline olan güven ve onunla husule gelen tehlikelerle, iptal sebeplerinden bir kısminı bertaraf etmek amacıyla kabul edilmiştir ${ }^{22}$. Bu sayedé resmi makamlar huzurunda yapılan sözleşmelere karşı ehliyet ve irade sakatlı̆g itirazının ileri sürülmesi güçleşir ${ }^{23}$. Böyle bir amaç taşınmaz satımı için verilen vekâletin de resmi şekle tâbi olmasını gerektirir ${ }^{24}$. Aksi halde taşınmaz satım sözleşmeleri konusunda satıcı veya alıcının birer vekil tayin etmek suretiyle satım işlemi hususundaki iradelerini şekilsiz olarak beyan etmeleri imkânı doğar ki, böyle bir sonuç, kanunun amacı ile bağdaşmaz ${ }^{25}$. Bu nedenle, taşınmaz satumı için verilen vekâlet de resmi şekilde yapılmalıdır ve bu bir geçerlik şartı olmalıdir. Öte yandan 1512 saylli NK.m.89'a göre, tapuda işlem yapılması için verilen vekâletnamelerin noter tarafindan re'sen dïzenlenmesi gerekmektedir ${ }^{26}$. Bu hükme göre, tapu dairesinde bir kimsenin imzası noter tarafından tasdikli vekâletname ile taşınmaz satım sözleşmesi yapması mümkün değildir ${ }^{27}$. Tapu ve Kadastro Genel Müdürlügü de, yayınladığı genelgelerle taşınmaz satımı için verilen vekâletin hiç olmazsa noter tarafından tasdik edilmesi şartını aramaktadır $^{28}$. TST.m.13 de böyle bir sonucu doğrulamaktadır ${ }^{29}$. Bu

20. Velidedeoğlu/Esmer, sh. 48-49.

21. Oruzman, sh. 41 .

22. Oğuzman, sh. 42 .

23. 3. HD. T. 1.3.1962, E. 1038, K. 1677 (Karar için bkz. Karahasan, M. Reşity Türk Borçlar Hukuku, C. 5, Ankara 1992, sh. 288).

24. Oğuzman, sh. 42 .

25. Oguzman, sh. 42; Ertaş, Şeref; Eşya Hukuku, Izmir 1989, sh. 123.

26. Yargttay, 6.6.1997 tarih ve E. 1994/5, K. 1997/2 sayll Içtihadh Birleştirme Karannda taşınmaz satım vaadi açısından NK. m. 89'un öngördüğ şekil şartını, geçerlik şarti olarak kabul etmiştir (YKD. 1997, S.9, sh. 1369 vd.)

27. Oxuzman/Seliçi, sh. 290 .

28. Bkz. Tapu ve Kadastro Genel Müdürtüğu'nün 10.11.1931 tarih ve 577 sayll; 1.9.1941 tarih ve 1021 sayll; 13.8 .1957 tarih ve 1285 sayll; 21.1.1957 tarih ve 1294 sayıl; 3.6 .1987 tarih ve 1431 sayil genelgeleri. 
göruş İsviçre ${ }^{30}$ ve Türkiye'de azınlıkta kalan bazı yazarlar tarafından savunulmaktadır ${ }^{3 !}$. Yargitay da bazı eski kararlarında ${ }^{32}$ bu göriişü kabul etmiştir.

Hakim görüşe göre ise, taşınmaz satımı için verilen vekâlet hiçbir şekle tâbi değildir ${ }^{33}$. BK. m. 11'deki şekil serbestisi ilkesi geçerliğini bu konuda da sürdürrmektedir ${ }^{34}$. Gerçekten de hâkim görüşe göre, taşınmaz satımına (ve alımına) yetki veriliyor olsa bile, vekâletnamenin geçerliği resmî şekilde yapılmış olmasına bağlı değildir ${ }^{35}$. Bu görüşün gerekçelerini genel olarak şöyle özetlemek mümkündür:

Medeni Kanun ve Borçlar Kanununda temsil yetkisinin ve vekâlet sözleşmesinin geçerliği için resmî şekil öngören bir hüküm

29. TST. m. 13/V "Istem vekaleten yapılmışsa vekjlden Noterlik Kanununa göre düzenlenmis ye istem konusu işleri yapmaya yetkili olduğunu içerir vekaletname istenir. Vekil, tevkil yețkisine dayah olarak bir başkasın vekil tayin etmiş ise, ayrica dayanăğ olan vekaletname de aranır. Vekilin kimliği saptandıktan sonra tapu sicilindeki hak sahibi ile vekaletnamedeki müvekkilin kimliği karşılaştırılı."

30. Bu konuda geniş bilgi için bkz. Kocayusufpaşaoğlu, Vaad, sh. $105 \mathrm{vd.}$

31. Arsebük, sh. 470 “...gayrımenkul satımtannın mümessil tarafından yapılması için resmî bir vekâletnameye ihtiyaç vardur. Gayrumenkul satımlarında resmî bir senede lüzum gösteren ve bu itibarla husule gelen akdin sonuçlan hakkında ilgilileri düşünmeye sevkeden kanun koyucunun, bu iş için temsil kudretinj tevfiz ederken iş bu noktayı ihmal etmiş olması bana imkânsız gibi görünüyor. Bu sebepten dolayı gayrimenkuliin devrini istihdaf bile vekâletin şekle tabi olmayacağı yolundaki görüşe ka-

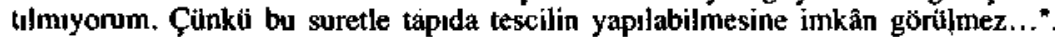
Aynca bkz. Óguzman/Seliçi, sh. 290; Şener, Esat: 1512 sayılı Noterlik kanununun 89. Maddesi Karşısında Mirasın Taksimi Sözleşmesi, TNBHD, S.II (1976) sh. 3 vd: Tekinay, S. Sulhi; Noterlik Kanınunun 89. Maddesi Hakkında Düşünceler, HUMK. nu Değiştiren 1711 sayılı Kanun ve Noterlik Kanunu Hakkında Sempozyum, Istanbul 1976, sh. 213 vd.

32. Y. 1. HD.'nin T. 21.1.1950, E. 1949/5706, K. 341 sayıl tararı: “...vekil adi bir vekâletname ile gayrimenkulün temlikine ait salih bir tasarruf getinneye yetkili değildir. Çünkỉ, vekâlet satuş sözleşmesinin esasılı bir unsurudur..." (TíK. 1950, C.I, Nr. 424).

33. Guhl,T/Merz,H/Druey, N.; Das Schweizerische Obligationenrecht, 8. Auf. Zutrih 1991, sh. 149, 496; Giger, Hans; Kommentar zum Schweizerischen Zivilgesetzbuch, Bd. VI, 2, 1, 3, Bem 1997, Art. 216, Nr. 188, 206; Kutlu-Sungurbey, Ayfer; Yetkisiz Temsil, istanbul 1988, sh. 68-69; Honsell, Heinrich; Schweizerisches Obligationenrecht Besonderet Teil, Bern 1991, sh. 210; Sirmen, sh. 293 vd; Karahasan, Borçlar, C. 4, sh. 215; Aynı yazar, Eşya, C.II, sh. 365; Feyzioglu, sh. 101; Aral, sh. 228;

34. Bu konuda geniş bilgi için bkz. Feyzioğlù, sh. 101; Kocayusufpaşaoğlu, Necip; Miras Hukuku, 3. Bası, İstanbul 1987, sh. 729.

35. Konuyu yetkisiz temsilci açısından inceleyen Kutlu-Sungurbey de aynı sonuca varmiştır. Yazara göre yetkisiz temsilcinin yaptı̆̆ı sözleşme geçerlik şartına bağlı olsa bile, bu sözleşmeye verilen onay hiçbir geçerlik şartına bağlı olmadan verilebilir. Alman Medeni Kanunu (BGB) \$ 182/I'ye göre de, muvafakat için hukukî işlemin bağlı olduğ şekil gerekli değildir. Geniş bilgi için bkz. Kutlu-Sungurbey, sh. 68-69. 
mevcut değildir. Bu nedenle, BK.m.11/I'deki genel kural gereğince, taşınmaz satımına ilişkin de olsa, temsil yetkisinin verilmesinin ve vekâlet sözleşmesinin şekilsiz dahi geçerliğini kabul etmek gere$\operatorname{kir}^{36}$ : Zira, ne vekilin ne de müvekkilin burada resmî şeklin korumasına ihtiyacı vardır. Çünkü, vekil, sonuçlarından etkilenmeyecek şekilde kendisinin değil, müvekkilinin işini görmektedir. Müvekkil ise, taşınmaz satım sözleşmesini yapıncaya kadar vekili azletmek imkânına sahiptir (BK. m. 396/I). Bundan başka, vekil müvekkil adına satım sözleşmesini yaparken zaten resmî şekilde uymak zorundadır ${ }^{37}$. Kald ki, BK.m. 390'ne göre vekil, borcunu ihlâl etmesi nedeniyle müvekile karşı sorumlu olmamak için işini özenle yapmak zorundadır. Böylece satım sözleşmesi yaplıncaya kadar her iki taraf da özenle hareket etmek durumundadır ${ }^{38}$. Vekilin borcu, vekâlet sözleşmesinin konusunu teşkil eden işe özen göstermekten ibaret olup, işin kendisi yani, üçüncü kişiyle satım sözleşmesinin kurulması değildir ${ }^{39}$. Meselâ vekil A, müvekkili B'ye ait taşınmazı C'ye devretmek için gerekli faaliyeti göstermekle yükü̈mlü olup, devirle yükümlä degildir. Böyle bir sonuç; vekilin borcunun bir vasita borcu (obligation de moyen) olduğunu gösterir ${ }^{40}$. Doktrinde hakim olan bu görüs ${ }^{41}$ uygulamada da hakim olmuştur. Gerçekten gerek Federal Mahkeme ${ }^{42}$, gerek Yargıtay $^{43}$, taşınmaz, satımı için

36. Becker, H. (çev. Suat Dura); Isviçre Borçlar Kanunu Şerhi, II. Bölitim Çeşitli Sözleşme lliskileri, Ankara 1993, m. 216, Nr. 6; Honsell, sh. 210; Eren I, sh. 525; von Tuhr, A JPeter, H.; Allgemeiner Teil des Schweizerischen Obligationenrechts, Bd. I, 3. Auf. Zürich 1979, sh. 355; Esener, Tuman; Salâhiyete Müstenit Temsil. Ankara 1961 sh. 240; Kocayusufpaşaoğlu, Vaad sh. 106; Aral, sh. 228; Tandoğan, J1, sh. 252, Esmer, Galip; Mevzuatımızda Gayrimenkul Hükümleri ve Tapu Sicili, 5. Basım, İstanbul 1990, sh. 716 vd; Tekinay/Akman/Burcuoğlu/Altop, Tekinay Borçlar Hukuku Genel Hükümler 7. Bası, Ístanbul 1993 sh. 173; BGE 99 II 159.

37. Tandoğan, $\mathbf{V} / 1, \mathrm{sh} .252$.

38. Postacıoglu, tlhan E.; Gayrimenkulün Ferağına Mïeallik Akitlende Şekle Riayet Mecburiyeti, Istanbul 1945 , sh. 98 vd.

39. Kocayusufpaşaoğlu, Vaad, sh. 106; Sirmen, sh. 293.

40. Kocayusufpasaoglu, Vaad, sh. 107.

41. Bu konuda genis bilgi için bkz. Sirmen, sh. 293; Karahasan, M. Resit, Türk Medeni Kanunu Esya Hukuku, C. II, Ankara 1977, sh. 385 vd; Kaneti, Selim; Yargitay Ictihat arına Göre Tasınmazlara Iliskin Islemlerde Sekil Sorunu, Medeni Kanun 50 . Yl Sempozyumu, C.I, Istanbul 1978, sh. 309; Postacioglu, sh. 97; Gürsoy/Eren/Cansel, sh. 479; Kurca, Ismail; Tican̂ Mümessilfik, Ankara 1996, sh. 123; Aral, sh. 228.

42. BGE 84 II 151 "...Konusu taşınmaz olan bir satım sözleşmesi yapılmasına ilişkin temsil yetkisinin resmî şekilde yapılması gerekmez. (Kaneti, Selim, Isviçre Federal Mahkemesinin Borclar Hukuku Kararları, C JI, Özel Borç liłşkileri, Ankara 1968 sh. 66); BGE 65 II 161: "Vekâlet verene devretmek için tașınmaz mallann iktisabına ilişkin vekâlet resmî bir senede ihtiyaç gơtermez...; BGE 81 II 231 : “... Vekilin, müvekkil adına ïçīincil sahısłarła akit yapmasına ilişkin vekâlet, yapılacak akit sekle tâbi olsa bile (mesefâ taşınmaz satım), şekJe tâbi deợildir. Vekílin úiçüncỉ şahıslarla satım akdi yapması vekâfetin konusu olmayıp, taahhut editen işin yerine getirilmesidir. ...; BGE 84 II $157 ;{ }^{*}$... Hem taşınmaz mallann satışına iliş̧kin temsil 
verilen vekâletin geçerlik açısında hiçbir şekle tâbi olmadığını kabul etmektedirler. Aynca Yargitay, bir İçtihadlı Birleştirme Kararında ${ }^{44}$ taşınmaz satın almak üzere verilecek vekâletin resmî şekilde yapılmasının gerekli olmadığına karar vermiştir.

Kanımızca, hakim görüş̧ haklı gerekçelere dayanmaktadır. Her şeyden önce, tapu işlemleri mutlaka malikin veya hak sahibinin bizzat gerçekleştirmesi gerekli işlemler değildir. Başka bir deyişle, tapudaki işlemler temsilciler tarafından da yapılabilir. BK.m.386 vd.da vekil aracılığı ile tapuda işlem yapılması halinde, verilecek vekâletin şekli konusunda hiçbir kayıt öngörülmüş değildir. Taraflar vekâlet sözleşmesini sözlï veya yazılı şekilde yapabilirler ${ }^{45}$. Hatta BK.m.387'de vekâlet sözleşmesinin zımnî olarak dahi kurulabileceği hükme bağlanmıştır. Bu sonuç da taşınmaz satımı konusunda verilecek vekâletin resmî şekle tabi olmadığını gösterir.

MK.m.634 ve BK.m.213'de taşınmaz mülkiyetinin devri borcunu doğuran sözleşmelerin resmî şekilde yapılması gerektiği açıkça ifade edilmiştir. Söz konusu maddelerde şekil geçerlik şartıdır. 3045 sayılı Kanunla da bu tür sözleşmelere resmiyet kazandıracak makam olarak; tapu müdürlükleri görevlendirilmiştir. Şu halde kanun koyucu taşınmaz mülkiyetinin devrini amaçlayan sözleşmelerde de vekâletin resmî şekle tâbi olmasını istemiş olsaydı bu yöndeki iradesini, kefalette olduğu gibi açıkça belirtirdi ${ }^{46}$.Vekâlet için herhangi bir şekil öngörmeyen kanun koyucu, bu davranışıyla bu sözleşmenin geçerlik açısından da şekle bağlı olmadığını belirtmek istemiş̧ir. Bu nedenle, vekilin yapacağ 1 işlem resmî şekle tâbi olsa bile vekâlet, geçerlik açısından hiçbir şekle tabî değildir. Aynı sonuca vekâletin zımnî kabulle tamam olacağını öngören BK.m. 387 hükmünden de varmak mümkündür ${ }^{\text {th }}$. İsviçre uygulaması da bu yöndedir ${ }^{48}$. Benzer bir sonuç, BK.m.450/II'de yer almaktadır. Buna

yetkisi, hem kocanın, karinın taşınmaz mallan ïzerinde tasamufta bulunmasına ilişkin izni, şekle bağhı olmadan geçerlidir. Sözlia, hatta zımnî bir davranışla izin verilebilir...). Ayrica bkz. BGE 64 III 28.

43. HGK. T. 9.10.1971, E. 4-661, K. 579 (ABD. 1972, S.2, sh. 296): 4. HD. T. 2.2.1971, E. 12001, K. 1048 (Renda, NJOnursan, G.; Borçlar Hukuku, C. I, Ankara 1972, sh. 610). 4. HD. T. 5.1.1978, E. 11251, K. 5 (YKD. 1979, S.3, sh. 344 vd).

44. Bkz. 7.10.1953 tarih ve E. 8, K. 7 sayılı IBK. (RG. 28.11.1953, S. 8589).

45. Yilmaz, sh. 13; Fellmann, Watter; Kommentar zum Schweizerischen Privatrecht, Bd. VI, 2, 4, Der einfache Auftrag, Art. 394-406 OR. Bern 1992, Art. 396, Nr. 83.

46. Honsell, sh. 210; Altaş, sh. 70 vd.

47. Honsell, sh. 210; Tandogan I., sh. 364.

48. BGE 112 II 332; 99 II 162. Aksi gơņ̇ için bkz. Leuenberger, Chritoph; Abschluss des Grundstikckkaufvertrages, in: Grundstückauf, Hrsg. Alfred Koller, St. Gallen 1989, sh. 75 . 
göre, ticarî temsilci açıkça yetki verilmiş olmadıkça, taşınmazı devir veya bir aynî hakla sınırlayamaz. Ticarî temsilcinin yapacağı hukukî işlem şekle bağlı olsa dahi, ona temsil yetkisinin verilmesi hiçbir şekle bağlı değildir ${ }^{49}$. Yeter ki, söz konusu vekâlet tapu memurunda o kimsenin vekil olduğu kanaatini oluştursun. Gerçekten de vekilin, üçüncü kişiler ve resmî makamlar karşısında vekil oldugunu isbat edebilmesi için vekâletin yazılı olmasında yarar vardır ve bunun için adi yazılı vekâletname yeterlidir ${ }^{50}$.

Tapu ve Kadastro Tapu Müdürlügüi'nün, kanunda yazılı olmayan bir şekil şartını, yayınladığı genelgelerle getirmesi mümkün değildir. Bu genelgeler, söz konusu kurumun merkez ve taşra teşkilatı arasında bir iç ilişkiden ibaret olup, tapuda işlem yapan iş sahiplerini bağlamaz ${ }^{51}$. NK.m.79/I de yer alan hükü̈m de ${ }^{52}$, bir geçerlik şartı değil, noterlerin uyması gereken bir düzen kuralıdıs3 . BK.m. 388/ III de, vekâlet vereni korumaya yönelik bir hükümdür ${ }^{54}$. Bu nedenle, vekâlet verenin korunmayı istemediği bir yerde, onun açık iradesine rağmen korumaya devam etmeye gerek yoktur.

Şekil, kural olarak tarafları düşünmeye sevketmek, acele karar vermelerini önlemek, dolayısile onlanı korumak amacına hizmet eder $^{\text {s5 }}$. Taraflarn böyle bir korumadan vazgeçerek, aralarında geçerli olduğunu kararlaştındıkarı adi yazılı vekâletnameleri kabul etmemek, her şeyden önce onların bu konudaki iradelerine saygı duymamak demektir. Oysa borçlar hukukunun temelini oluşturan sözleşme özgürlüğ̈i, taraflann iradelerine saygı esasına dayanır. Kaldı ki, kanunun, resmî șekli öngörmekle güttügüu, tarafları ikaz ve koruma amacmnt vekâlet sözleşmesi gerçekleştirecek niteliktedir. Aynca, kanun koyucu şekil serbestisi ilkesini benimsemiştir. Onun için şekle bağlı işlemleri istisnaen benimsemiş ve bu istinaları da açıkça belirtmiştir. Bu nedenle, istisnalann genişletilmemesi ilkesi

49. Bu konuda geniş bilgi için bkz. Kırca, sh. 124.

50. Guhl/Merz/Koller, sh. 150; von Tuhr/Peter, sh. 364, not. 52; Velidedeog/lu/Esmer, sh. 54; Postacioğlu, sh. 99-100; Kocayusufpaşaoglu, Vaad, sh. 107; BGE 56 II 266; 12. HD. T. 21 A.1986, E. 10465, K.4612 (Dalamanl//Kazanct/Kazanct, IV, Jlmî ve Kazaî Içtihatlarla Türk Borçlar Kanunu C., Jstanbul 1990 sh. 55-56).

51. HGK. T. 9.10.1971, E. 4-661, K. 579 (ABD. 1972, S.2, sh. 296).

52. NK.m.79/ şu hükmï içermektedir: "Vekil, veli, vasi, kayyım, mümessil ve mirasçı stfatıyla veya şirket ve demek gibi tüzel kişiler adlarına noterlik ișlemi yapmak isteyenler, sıfat ve yetkilerini ve işlemi yapmaya izinli olduklannt bildirir belge göstermekle yükïimlüdürler".

53. Hatemi, H/Serozan, R/Arpacı, A. Eşya Hukuku, İstanbul 1991 sh. 545.

54. Guhl/Merz/Koller, sh. 150.

55. Bu konuda geniş bilgi için bkz. Eren, sh. 328 vd.; Altaş, sh. 67. vd. 
uyarınca, şekle bağlı işlemlerin sayısının artırılmaması gerekir. Bu konuda kanunlarda yer almayan yeni bir şekil kuralı getirilmemelidir. İsbat açısından kolaylık, güvenlik sağlayan şekil mecburiyetine dayanarak, genel isbat şekli kuralları ihlâl edilmemeli, iki husus birbirine karıştırılmamalıdır ${ }^{56}$.

Vekil, vekâlet sözleşmesinde müvekile ait bir işi görmektedir. Burada sözleşmenin içeriğini, vekilin, hukukî işlemi yapma suretiyle hizmet görmesi şeklinde borç altına girmesi oluşturmaktadır. İşin göriilmesi ise, sözleşmenin kurulması değil, ifa aşaması ile ilgilidir. Bu açıdan da taşınmaz satımı için verilen vekâletin resmî şekilde yapılması gerekli değildir ${ }^{57}$.

BK.m.388/III'de taşınmaz satımı için verilen vekâlet konusunda özel yetkiden ${ }^{58}$ söz edilmekte ise de, bu bir geçerlik şekil şartı değildir ${ }^{59}$. Bir an için taşınmaz satımını içeren vekâletin resmî şekilde yapılması gerektiğini kabul edelim. Böyle bir halde resmî şekil aranacaksa, bunun dayanağı BK.m.11 ve NK.m.89 olamaz. Aynı şekilde taşınmaz satımı için resmî şekil aranması konusunda Yargıtay'ın miras taksim sözleşmesi ile ilgili İçtihadı Birleştirme Kararı$\mathrm{na}^{60}$ da dayanmak mümküin değildir ${ }^{61}$. Çünkü, söz konusu İçtihadı Birleştirme Kararında da belirtildiği gibi, NK.m. 89, MK.m.611'i

56. Geniş bilgi için bkz. Eren, sh. 359; Kılıçoğlu, Ahmet; Miras Taksim Sözleşmesi, Ankara 1989, sh. 91 vd.; Yavuz, Cevdet; Türk-Isviçre ve Fransız Hukuklarında Dolaylı Temsil, Istanbul 1983 sh. 152; Akyol, Şener; Dürtistlük Kuralt, İstanbul 1995 sh. 68 vd.

57. BGE 81 II 227 “...Ücüncü kişi ile satum sözleșmesinin yapılması, vekâletin konusu deģil, taahhiit edilen hizmetin ifasıdır. Vekil borcunı ifa etmekten kaçındı̆̆ takdirde sorumlulugu, satın alma vaadine göre değil, OR. Art. 397 (BK. m. 389) ve devamına göre belirlenir..." Bu konuda geniş bilgi için aynça bkz. Tandoğan If, sh. 387 vd; Yavuz, Temsil, sh. 149.

58. Vekâlet sözleşmesinde özel yetkiyi gerektiren haller ile özel vekâletname ayrımı konusunda geniş bilgi için bkz. Yılmaz, sh. 14.

59. Vekile, belli bir işlemin veya eylemin yapılması için verilen yetkiye özel yetki denir. Müvekkil, vekiline meselâ, “...İli, ...İ̀lçesi, ....Mahallesi, ....Sokak, No...'da bulunan taşınmazı satmaya... biçiminde yetki vermişse, buna özel yęki, böyle bir yetkiyi içeren vekâletnameye de ôzel vekẩletname denir. Bkz. Yılmaz. sh. 14.

60. YİBK. T. 10.11.1952, E. 2, K.4. Söz konusu IBK.'nda terekede taşınmaz mallar bulunsa bile, miras taksim sözlesmesinin adi yazılı sekilde yapılabileceğgi kabul edismiştir. (Söz konusu IBK. özetle şöyledir: "Mirasa dahil taşınmazların taksimi hakkında, yapılacak sözleşmenin geçerli olması için, yalnız yazılı olması yeterli olup bu sözleşmenin ayrıca tapu memurunun huzurunda resmi senede baglanması mecburiyeti yoktur... ${ }^{*}$ Sener, sh. 229, sh. 455-465). 8. HD. T. 17.11.1986, E. 1086/10771, K. 1986/11105 ... Taksim sözleşmesinin yazilı olması yeterli olup, noterde dizenlenmesi geçerlik koşulu de ̧̧ildir... (YKD. 1987, S. 3, sh. 411-412). Geniş bilgi için aynca bkz. Zeyneloğlu, Ahmet; Mukavelelerinin Geçerli Olabilmesi Için Noterlikçe Re'sen Dizenlenmesi Gerekli Dezildir, TNBHD. S. 27 (1980), sh. 3 vd.

61. Hatemi /Serozan /Arpaci, sh. 547. 
yürürlükten kaldırmış değildir ${ }^{62}$. Zira, Noterlik Kanununun, maddî hukuk kurallarını değiştirme gibi bì fonksiyonu bulunmamakta$\mathrm{dtr}^{63}$. Ayrıca kanun koyucunun burada böyle bir amacıda söz konusu değildir. Kanun koyucu eğer böyle bir amaç güitmïş olsaydı, bunu açıkça ifade ederdi. Sadece $m .89$ 'un metninde değil, Noterlik Kanununun tamamında böyle bir ifade yer almamaktadır. $\mathrm{Bu}$ nedenle, söz konusu maddeden ve İçtihadı Birleştirme Kararından hareketle, taşınmaz satımı için verilen vekâletnameler için resmî şekil şartı öngördü̈łü sonucuna varılamaz. Öte yandan NK.m.89'un açık olmayan ifadesinden zorlama ile temel kanunlardaki hükmün deģiştirildiği sonucunada varmak mümkün değildir. Gerçekten de, özel kanunlarla getirilen şekil kurallarında Medeni Kanun ve Borçlar Kanunundaki şekil ile ilgili hükümlere hiçbir surette dokunulmamıştır. Ayrıca 1512 sayılı Kanunla, Medeni Kanun hükümlerinin değiştirildiğine dair bir hüküm de mevcut değildir. Özel kanunlarda hukukî işlemlerle ilgili olarak öngörülen şekil hükümleri maddi hukuka ait ve esas hakkında değişiklik getirmedikçe, ancak isbat açısından önem taşırlar. Şekil serbestisi ilkesinin zedelenmemesi için

62. Eren, sh. 349. Cumhuriyet Senatosu Geçici Komisyon Raponundan: “...Tasarınm 89. Maddesinin... Türk Medeni Kanunu mliesseselerinin özellikle miras hükümleri-

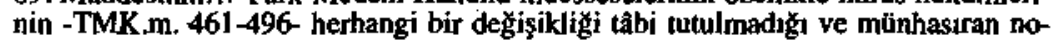
terde yapılacak işlemlerin düzenlenmesinde uyulacak hükümlerin saptanmış olduğo hususunu bir açıklama olarak komisyon raporuna dercetmeyi de karar altına almuş. tur..." (Öktemer, Semih; 1512 sayti Noterlik Kanunu Açısından Mirasın Taksimi Sözleşmesi, TNBHD. S. 14 (1977) sh. 37'den naklen.) 3. HD.'nin T. 24.4.1979, E. 1979/2774, K. 1979/2851 kararndan:" ...Noterlik Kanununun 89. maddesi hükmi., miraş̧ıların taksim mukavelesi yapılması için notere başvurduklarında, bu sözleşmenin noterde nasil yaptlacağını açıklamsştı. Noterlik Kanunı miras hukuku ile ijgili müesseseleri d(uzenleyen bir kanun olmadığından bu kanunla ancak, noterlikjlein (kanimızca noterlerin olmast gerekir) yiukümlïlük ve haklan, sorumlułuk ve ücretleri, hukukî güvenliğin sağlanması ve işlemlerin belgelendirilmesi düzenlendiginden, sözü geçen 89. maddenin özel hüküm niteliğini taşıyan MK. m. 611. maddenin son fikrasını yürtirlükten kaldırdığından söz edilemez... (YKD. 1979, S. 8 sh. 1125-1126).

63. Bkz. Öktemer, sh. 32 vd: Tandoğan, $\mathbf{L} /$, sh. 253-254; Kılıçoğlu, sh. 91. Zeyneloğlu, sh. 3-4; Ústündağ. Saim; Medeni Yarglama Hukuku, Istanbul 1989, sh. 624; BGE 118 II 395; HGK. T. 9.6.1976, E. 1975/2-805, K. 1976/2205 (YKD. 1977, S.6, sh. 752-753). MK.m. 634, ve BK.m.213'de öngörülen resmî şekil, taşınmaz mülkiyetinin naklini amaçlayan sözleşme için geçerli olup, vekâlet sözleşmeși için değlldir. Yavuz, Temsil, sh. 15I. Gerçekten de, NK m. 89'un amaca göre yonumlanmasından, yazılıs tarzundan ve Seneto Geçici Komisyonu raporundan, aynı maddede yazılı işlemler için notere başvuruldúğ takdirde, noterin bu resmî iş̧emi naşıl gerçekleştireceģini öngören bir düzen usulünü öngördügü anlaşılmaktadır. Ayni sonuca Kadastro Kanunu m, 15'đen hareket ederek de varmak mümkündür. Buna göre, tapulu olsun veya olmasın kanunun kapsamına giren taşınmazlarn miras yoluyla elden taksimi geçerli ve bunun tanık beyanıyla isbatı kabul edilmiştir. Kanun koyucunun bu konudaki amacı resmî şekil olsaydı, bunu Kadastro Kanununda da ortaya koyandt, Geniş bilgi için bkz. Kulıçoğlu, sh. 93 . 
özel sekil kurallarının ve usul kurallarının dar yorumlanması gerekir. Bu nedenle NK.m.89'un kenar başlığında yer alan "Niteliği bakımından tapuda işlemn yapılmasını gerektiren sözleşme" deyiminin, Medeni Kanun ve Borçlar Kanununda aynntılı bir şekilde dïzenlenmiş diğer sözleşmeler ile ilgili şekil kurallarını değiştirdiği şeklinde yorumlanması mümkïn değildir.

Vekâlet ilişkisinin noter tarafından belgelendirilmesi zorunluluğu hiçbir zaman geçerlik şartı olarak görülemez. Bu hüküm kendine başvurulan noterin söz konusu işlemleri, çeşitli işlem şekillerinden hangisine göre yapacağı konusunda yol gösteren bir kuraldır. NK.m.89, burada sayılan işlemler için geçerlik şekli öngören bir hüküm olmayıp, olsa olsa isbat şartı olabilir ${ }^{\text {ti. }}$. Bu nedenle, tapu memuru noter tarafından re'sen düzenlenmiş dełil de, imzası tasdikli bir vekâletnameye dayanarak, taşınmaz satım sözleşmesini düzenleyip, buna istinaden tapuya tescil işlemini yaptığı takdirde, söz konusu tescil geçerli bir işlem olur ${ }^{65}$.

\section{2) İspat açısından:}

\section{a) Genel olarak}

Taşınmaz satımına ilişkin vekâletin geçerlik açısından hiçbir şekle tâbi olmaması, onun ispatı için bazı şekil şartlarının aranmayacağı anlamına gelmez. Bazı yazarlara göre ${ }^{66}$, taşınmaz satımında vekilin, sıfatını ispat etmek üzere imzası noter tarafından onaylanmış bir vekâletname ibraz etmesi gerekir. Buna karşılık, Tapu ve Kadastro Genel Müdürlügüü yayınladığı bir genelge ile $^{67}$ imzaları noter tarafindan onaylanmış vekâletname ibrazını yeterli bulmamakta, herhalde vekâletnamelerin re'sen düzenlenmiş olmasını aramakta, söz konusu nitelikleri taşımayan vekâletnamelere dayanan taleplerin kurum memurları tarafından reddedilmesi gerektiğini bildirmektedir. Kanuna dayanmayan böyle bir şartın ỉçüncü kişileri bağlayıp bağlamayacağı tartışmalara yol açmı̧ ve Yargıtay içtihadina ${ }^{68}$ konu olmuştur.

64. Öktemer, sh. 35-37; Ustïnda , sh. 625-626.

65. Italyan Medeñ Kanunu bu konuda açık bir hilküm öngörmektedir. Gerçekten, CCI. Art. 1392'ye göre, resmî şekle bağl bukukî işlemlerin yapılması için verilen vekâletlerin de resmî şekilde yapılması gerekir. Aynca bkz. Hofstetter, Joseph, Basler Kommentar, Bd. VII/2, Basel 1979, sh. 42; Gautschi, Georg; Kommentar zum Schweizerischen Privatrecht, Bd. V1, 2, 4, Der einfache Auftrag 3. Auf. Bern 1971 Art. $396, \mathrm{Nr} .9 \mathrm{c}$.

66. Postacioğlu, sh. 99-100.

67. Bkz. 21.1.1958 tarih ve 1294 sayıl genelge. Bu genelge, 13.8.1957 tarih ve 1285 sayılı genelgenin ekidir.

68. HGK. T. 9.10.1971. E. 4-661, K. 579 (ABD. 1972, S. 2, sh. 296). 


\section{b) Doktrindeki görü̈sler:}

1512 sayılı NK.m.89'a göre niteliği bakımından tapuda işlem yapılmasını gerektiren sözleşme ve vekâletnamelerin düzenleme şeklinde yapılması zorunlu işlemlerdir. Söz konusu hüküm Medeni Kanun ve Borçlar Kanununun şekil ile ilgili hükümlerinin aksini öngördü̈̈̈̈nden, doktrinde çeşitli görüşlerin ortaya çıkmasına neden olmuştur. Bu konuda başlıca iki görüş bulunmaktadır.

Bir görüşe göre ${ }^{6}$, NK.m.89 Medeni Kanun ve Borçiar Kanununun şekil ile ilgili hükümlerini değiştirmiştir. Bu görüşüi savunan yazarların gerekçelerini şu şekilde özetlemek mümkündür:

Noterlik Kanunu'nun yürürlüğe girdiği 5.5.1972 tarihinden beri niteliği bakımından tapuda işlem yapılmasını gerektiren vekâletnamelerin resmî şekilde yapılması gerekir. Zira Noterlik Kanunu usule ilişkin bir kanun değildir. Noterler maddî hukuk bakımundan geçerlikleri şekle bağlı olan hukuki işlemleri de düzenlemekle görevlidirler. Bunun isbatı NK.m. $60^{\prime}$ dır. Bu görüşü savunan yazarlara göre, kanunlardaki resmî şekit şartı, hiçbir zaman bir usul işlemi, isbat şartı olarak düzenlenmiş değildir. Bunun sonucu olarak resmî şekil mecburiyeti bir kanun hükmünün sırf isbat kolayltğı amacını gütttüğï iddiası da doğru değildir ${ }^{20}$. Aynı şekilde NK.m. 89 'un ne lâfzından ne de içeriğinden notere başvuruldugunda o işlemin noter tarafından nasıl yapılacağını gösterir niteliktedir" Zira söz konusu madde burada yer alan işlemlerin nasıl yapılacağını öngörmüistürr. Bu hükümden sonra tarafların NK.m.89'da yer alan işlemleri adî yazılı şekilde yapma imkânları ortadan kaldırmıştır. Bu nedenle, resmî şekil burada ispat değil geçerlik şartıdır ${ }^{72}$. Zira, NK.m.89'un kenar başlığı "düzenleme şeklinde yapilmast zorunlu isslemler" dir. Bu, notere verilen bir talimat değildir. Eğer böyle bir durum olsaydı, kurala uyulmaması sonucunda, noterin bilgisizliği veya hatasindan tarafların zarar görmemesi gerekirdi. Oysa, NK.m. $89^{\prime}$ 'a yazılı olup da düzenlemle şeklinde yapılmayan işlemler hüküm ifade etmez. Söz konusu maddenin kenar başlığındaki

69. Gerçekten de NK.m.60'da 9 bent halinde, genel olarak noterlerin yapacaklar işlemler sayıJırken, maddi hukukJa ilgili olarak; taşınmaz satım vaadi yapmak, kanunen tescili gereken işlemieri yapmak..." gibi ifadelere yer verilmiştir.

70. Tekinay, Düş̧inceier, sh. 217, Ayn yazar Eyşa Hukuku, C.I, 4. Bası, İstanbul 1984, sh. 301-302.

71. Tekinay, Düşinceler, sh. 217.

72. Vural, Perihan; Noterler Yönünden Temsil ve Vekâlet, Temsił ve Vekâlete Illişkin Sorunjar Sempozyumu, Istanbul 1977, sh. 191. 
“zorunluluk" kavramı, geçerlik şartı olarak anlaşılmalıdır ${ }^{\text {’3 }}$ Bu nedenle, NK.m.89, Medeni Kanun ve Borçlar Kanunundaki şekille ilgili kurallarda değişiklik yapmıştır.

Başka bir görüişe göre, NK.m. 89, Medeni Kanun ve Borçlar Kanununđaki şekille ilgili hükümlerde değişiklik yapmamıştır. Zira NK.m.89, taşımmazlara ilişkin olup da tapuda işlem yapılmasını gerektirmesine rağmen Medeni Kanun ve Borçlar Kanunundaki resmi şekle tâbi tutulmayan işlemler yine eskiden olduğu gibi, resmi şekilden muaftır. Çünkü, NK.m.89, ne bir ispat ne de bir geçerlik şartı getirmiştir. Söz konusu madde, doğrudan doğruya noterlere yöneliktir ${ }^{74}$. Noterlik Kanununun maddi hukuka etkisi olamaz. Bu nedenle, Noterlik Kanunu maddî hukukun şekil kurallanın değiştiremez. Çünkï şekle bağlı olmayan maddi hukuk işlemlerinin geçerlik şartına bağlı tutultmaması, yine maddi hukuka ilişkin kuralların zedelenmemesi gerekir ${ }^{73}$. Kaldı ki, NK.m.89'un kaleme alınış tarzından burada sayılan işlemler için bir kimsenin notere başvurduğu takdirde noterin bu işlemi nasıl yapacağını hedeflediği, yoksa bu işlemler için geçerlik şartı getirdiği sonucu çıkarılmaz" ${ }^{36}$. Aksi fikir Medeni Kanunun temel ilkelerine ters düşer ${ }^{n}$. Doktrinde hakim olan görüş de budur ${ }^{78}$.

c) Kişisel görüşümüz.

Kanımızca hakim göriłşe katılmak gerekir. Şöyle ki, taşınmaz mülkiyetini devreden sözleşmelerin resmi şekilde yapılması getektiǧi MK.m. 634 ve BK.m.213'de belirtilmiştir. Aynı ş̧ekilde TK.m.26'da bu tür sözleşmelere resmiyet kazandıracak makam olarak tapu sicil muhafizlar ve memurları, 3045 sayılı Kanun ile de bu konuda tapu müdürlükleri yetkili kılınmışlardır. Tapu memurunun fiil ve işlemlerinden dogan zararlardan devletin sorumlu olduğu MK.m. 917'de hüiküm altına alınmıştır. Bir an için, noter tarafından yapılan bir işlemden taraflann zarar gördüğünii kabul edelim. Böyle bir zarardan, tapu memurlan gibi, devleti sorumlu tutmak mümkün müdür? Bu soruya olumsuz cevap vermek gerekir. Yani,

73. Sener, sh. 5-6.

74. Esmer, sh. 721; Gürsoy/Eren/Cansel, sh. 479 vd; Feyzioğlo, sh. 101; Tandogan, I/1, sh. 243 vd; Kocayusufpassaoğlu, Miras, sh. 729 vd; Karahasan, Eşya, sh. 365.

75. Tandoğan, $\mathrm{V} 1$, sh. 257 ; Oklemer, sh. $32 \mathrm{vd}$.

76. Tandogan, $/ 1$, sh. 254; Feyzioglu, sh. 101-102.

77. Gúrsoy/Eren/Cansel, sh. 261-262,478 vd.; Ulukapı, Ö /Atal, M. Noterlik Hukuku Konya, 1994 sh. 139.

78. Bu göriłs Türk hukukunda İmre tarafundan savunulmaktadır. Bk. İmre, Zahit; Mirasın Taksimi Sözleşmesinip Şeki] Şartı ve Türk Medeni Hukukunun Buna llişkin Meseleleri, Onar Armağant, Istanbul 1977, sh. 409 vd. 
noterin yaptığı hatalı bir işlemden dolayı devletin sorumluluğı söz konusu değildir. Öte yandan Yargıtay'ın bir kararında haklı olarak belirttigi gibi ${ }^{79}$ Noterlik Kanunu, maddi hukuka ilişkin bir kanun olmayı, noterlerin hakları, yükiìmlülükleri, sorumluluklan, üicretleri, hukuki güvenliklerinin sağlanması ve işlemlerin belgelendirilmesi... gibi hususları düzenlemektedir. Bu amaçla getirilmiş hükümlerin Medeni Kanun ve Borçlar Kanununun temel hükümlerini değiştirmek amacını taşıdığinı söylemek mümkün değildir. Noterlïk Kanunun yapısı da amacının, Medeni Kanun ve Borçlar Kanununu değiştirmek olmadığını göstermektedir Bu nedenle NK.m.89, Medeni Kanun ve Borçlar Kanununda yer alan şekil kurallarında bir değişiklik yapmamıştır. Ayrıca, NK.m. 89'un kaleme alınış şekli de, söz konusu işlemler için notere başvurulduğunda, noterin bu işlemleri ne şekilde yapacağına yönelik bir kural olduğunu göstermektedir. Noterlik Kanununun bazı işlemler için şekil şartı öngörmüs olması, onun Medeni Kanun ve Borçlar Kanununun şekil ile ilgili hükümlerini de değiştirdiǧi anlaminda yorumlanamaz. $O$ halde taşınmaz satımı için verilen vekâletin BK.m.11'e göre istenilen şekilde yapılabilmesi gerekir. Yeter ki tapu memuru vekilin yetkisi konusunda yeterli bir kanaate ulaşmış olsun ${ }^{80}$. Böylece NK.m.89 ile Tapu ve Kadastro Genel Müdürlügünün genelgesi ${ }^{81}$ arasında bir uyum saglanmış olmaktadır. Yargıtay, miras taksim sözleşmesi açısından da aynı sonucu kabul etmiştir. Bu konudaki tereddütleri ortadan kaldırmak amacıyla bir kanun değişikliğine gitmek de fayda vardir ${ }^{82}$.

\section{Taşmmaz Satımında Vekâletin Kapsamı}

\section{A. Genel Olarak:}

Taşınmaz satımında vekâletin şekli kadar, kapsamı da önemlidir. Gerçekten taşınmaz satımını öngören vekâletname ister noter tarafundan re'sen düzenlenmiş olsun, ister tasdik edilmiş olsun,

79. 3. HD. T. 24.4 .1979$, E. 2774, K. 2851 (YKD. 1979, S. 8, sh. 1125-1126.

80. Tandoğan, I/, sh. 253; Feyzioglu, sh. 102; Öktemer, sh. 38; Kaneti, sh. 309; Kurca, sh. 124-125.

81. Bkz. 21.8.1958 tarih ve 1294 saylı genelge. Metin için bkz. Esıner, sh. 723-724.

82. Feyzioğlu, sh. 104; Xarahasan, Eşya, sh. 365; Ulukaps/Atalı, sh. 140 . Aynca bkz. 26.11.1980 tarih ve E.5, K.3 sayıli YIBK: *'..1512 sayulı Noterlik Kanumu m. 89, MK.m. 611/భ'ne dokunmuş değildir. Mirasçılar böyle bir sözleşmeyi yazılı da yapabiliter. Bu hedesle 1512 saysl NK. nun yürirltuge girdiłi tarihten sonra MK. m. 611 II'ma göre yapılan miras sözleşmeleri de geçetlidir ve NK.m.89, MK.m.61 1//I hửkmünü değiştirmemiştir..." Ozüarn, Ruhi; Açıklamalı Noterlik Kanunu, 3. Bası, Ankara 1987, sh. 81. 
önemli olan onun muhtevası ve vekilin haiz olduğu temsil yetkisinin kapsamıdır. Zira BK.m.388'e göre, "Vekâlet akdinin şümulü mukavele ile sarahaten tespit edilmemiş ise taalluk eylediği işin mahiyetine göre tayin edilir". Aynı maddeye göre, "hususi bir salâhiyeti haiz olmadıkça vekil... bir gayrimenkulä temlik veya ayni bir hak ile takyid edemez". Görülüyor ki taşınmaz satımı için vekilin özel bir yetkiye sahip olması gerekmektedir.

\section{B. İşlemler Açısından Vekâletin Kapsamı:}

\section{I) Yapılan işlemin niteliği açısından:}

Her şeyden önce taşınmaz satımı için genel bir vekâletname yeterli değildir. Çünkü genel vekâletname BK.m.388/llI'na göre aranan özel yetkiyi ihtiva etmez. Aynı şekilde özel yetkinin açıkça verilmiş olması gerekir ${ }^{83}$. Bu bakımdan satış için verilen vekâletname ipotek veya irtifak hakkı kurulması yetkisini vermeyeceği gibi bağışlama yetkisini de vermez ${ }^{84}$. Bu nedenle, vekâletnamede, mesela, "vekilim A,... yerdeki... kapı numaralı taşınmaz üzerinde her türlü tasarrufta bulunmaya yetkilidir" seklindeki bir kayıt, özel yetki sayılmaz. Çünkü, böyle bir yetki hükmü yeterince açık değgildir" ${ }^{8 s}$. Zira, böyle bir vekâlette yer alan "her türlï tasarruf" son derece genel ve belirsiz oldugu gibi kanunun özel yetki aradığı işlemler açısından da zararlıdır ${ }^{86}$.

\section{2) Taşınmazın yeri ve nitelikleri açısından:}

Taşınmaz satımı için verilen vekâlette, özel yetkinin, taşınmazın yeri ve nitelikleri açısından da büyük önemi vardur. Çünkü, müivekkil, böyle bir yetkiyi vermeden önce, belirli bir tasarruf ve bunun sonuçlarmı düşünmek ve daha dikkatli davranmak durumundadır. Bu bakımdan meselâ “....vekilim A, Türkiye'deki bütün taşınmazlarım üzerinde... yetkilidir" gibi bir ifade içeren vekâlet, vekili bir taşınmazı satmaya yetkili kılmaz ${ }^{k 7}$. Çünkü böyle bir kayıtta, hangi taşınmaz için ne tür işlemin yapılacağı belirtilmiş değildir.

83. Tandogan, II, sh. 398-399; Esmer, sh.728.

84. Esmer, sh. 728 .

85. Velidedeoğlu/Esmer, sh. 41.

86. Esmer, sh. 728; Velidedeo glu/Esmer, sh. 41; Vekâletname ile vekile tanınan "diledigi bedelle dilediği kişilere satıs yetkisi BK. m. 389'a uygun değildir. Benzer görüş için bkz. 13. HD. T. 17.4.1986, E. 1970, K. 2340 (YKD. 1986, S. 4, sh. 578-579).

87. Esmer, sh. 729; Ertaş, sh. 123; Yılmaz, sh. 18; Aksi görüs için bkz. Karahasan, sh. 366; Yildız, sh. 36. 14. HD. T, 6.4.1977; E. 1832, K, 3634 (Dalamanl/Kazancd Kazanci, IV, sh. 63-65). 
Oysa sadece karşılıklı güven esasına dayanan vekâlette ${ }^{88}$ bu derece geniş ve taşınmazlar için yaptlacak işłemin türü ve onların nitelikleri hakkında bir bilgi mevcut değildir ${ }^{89}$. Bu kadar geniş bir yetki, olsa olsa vekilin, müvekkilin talimatını alarak yetkisini kullanmasinı gerektirir ki, bu, bir iç ilişki olup, sadece vekil ile müvekkili ilgilendirir ${ }^{90}$.

Öte yandan bir vekâletname ile birden fazla taşınmazdan bazılan için satış, bazıları için ise sınırlı bir aynî hakla yükümlendirme yetkisi veriliyorsa; hangi işlemi yapma yetkisi verildiği açı̧ka belirtilmelidir. Ayrıca bu yetkide taşınmazın özellikleri de belirtilmelidir". Vekâletnamenin baş tarafında "genel vekâletname" ibaresi bulunsa bile, içeriğinde taşınmaz satım yetkisi bulunduğu takdirde, bunun, BK.m.388/III'de öngörülen özel yetkiyi kapsadı̆̆ı sonucuna varmak gerekir. Bu konuda vekâletnamenin çerçevesine değil, içeriğine bakmak gerekir ${ }^{2}$.

\section{3) Vekilin yetkileri açısından:}

Vekil, muivekkilinin, yetkilerini daraltan şart ve talimatlarına da uymak zorundadır. Zira, böyle bir şart sözleşmenin sonuçlarını

88. 1. HD. T. 2.10.1995, E. 1995/11443, K. 1995/12592: “...Vekilin borçlarının cogu... guven unsurundan dogar..." (YKD. 1996, S.2, sh. 198-200). 13. HD'nin, T. 3.10.1995, E. 1995/6697, K. $1995 / 8386$ sayılı kararından; “... Vekâlet sözleşmesi büyüik ölçüde vekil ile vekil edenin karşılıklı güvenine dayanır. Vekilin borçlarından önemli bir bölïmü bu güven unsurundan kaynaklanir..." (YKD. 1996, S.2, sh. 236240).

89. Esmer, sh. 730-731.

90. Velidedeoğlu/Esmer, sh. 41 13. HD.'nin T. 3.10.1995, E. 1995/6687, K. 1995/8386 sayılı karan: “...Köÿ̈ hudutlar dahilinde mevcut 156, 162 parsel numaralarunda kayıtlı gayrimenkullerdeki hisselerinin bir kısmı veya tamamını, beni temsilen dilediği bedel ve şartlarda dilediğine icara vermeye... mezun ve yetkilidir kaydun bulunması, ona (vekile) dürüstlük kurallarını, sadakat ve özen bofcunu gözardı ederek kiraya verme hakkı vermez. Yapılan işlem temsil yetkisinin sınırlan içerisinde kalsa dahi vekilin bu yưlkümlüJügüi daima mevcuttur... (YKD. 1996, S.2, sh. 236-240).

91. Esmer, sh. 731; Ertas, sh. 123; Yılmaz, sh. 18.

92. 14. HD. T. 6.4.1977; E. 1832, K. 3634 (Dalamanlı/Kazanc1/Kazancı, IV, sh. 63-65). Kararda davacılar vekilin, murisin verdiği vekâlete dayanarak devrettił̌ taşınmaz satımunun iptalini istemektedirler. Yargıtay burada, davacıların iyiniyetli olmadıklan sonucuna varmıştır. Karara göre vekil, müvekkilin verdigi vekâletnameye dayanarak işlemler yapmıştır. Mạ̈vekkil sağ konusu işlemlere, mülvekkilin ölömündẹn itibaren on yl gibi uzun bir süre itiraz etmemişler, daha sonra da satımın iptali için dava açmışlardır. Böyle bir davayı reddetmek gerekir. Zira söz konusu slíre mirasçlann bu satıma icazet verdikleri şekilde youmlanabilir. Karanda belirtildiğı gibi, ülkemizdeki para değerindeki yıllık değer kaybı oranları dikkate alındığında, davacıların söz konusu taşınmazı yok fiyatına geri almak niyetinde oldukları anlaşılır. Kanımızca böyle bir hareket MK. m2/I ile de bałgdaşmaz. Böyle bir duruma engel olmak gerekir. Aynı yönde karar için błz. Y 13. HD. T. 22. 4. 1986, E.1900, K. 2430 (Karahasan, Borçlar, C.6, sh. 661). 
da etkiler. Buna göre vekilin, taşınmazı vekâlette belirtilen bedelin altında bir bedelle bir satması söz konusu olamaz. Aynı şekilde vekâletname ile vekile verilen "dilediği bedelle, dilediği kişilere satma yetkisi" ona, söz konusu taşınmazı çok düşük bedelle, başka bir deyissle yok fiyatına satma ve müvekkilini zarara sokma yetkisi vermez ${ }^{93}$.

Vekile özel yetki verilmesi gereken hallerde bu yetkinin açıķa verilmiş olması gerekir. Özel yetkinin zımnî olarak verildiği kabul edilmemektedir. Ozel yetki gerektiren halde, bu yetki açıķa verilmemişse, vekilin söz konusu işlemi yapma yükümlülüğgü bulunmadığı kabul edilmektedir ${ }^{\text {y4 }}$.

Vekâletnamede vekilin, sadece taşınmazı satmaya yetkili oldugu belirtilmiş, tescil işleminden söz edilmemişse, onun tescil talebinde bulunabilmesi mümkün müdür? Böyle bir soruya Tapu ve Kadaștro Genel Müdürlüğü, yayınladı̆g bir genelge ${ }^{95}$ ile olumlu cevap vermiştir. Buna göre, "tescil, başlı başına satış akdinden ayrı olarak mevcut olamayacă̆ından, bu sebeple vekâletnamede tescil yetkisi açıkça yasaklanmamışsa, satış için verilen yetki, aynı zamanda tescil yetkisini de kapsar ${ }^{96}$. Doktrinde de farklı gerekçelerle aynı sonuca varılmıştır" Bu sonuç MK.m.642'nin temel amacına da uygundur ${ }^{98}$.

4) Vekilin satışa yetkili olduğu taşınmazı kendisi için satın alması açısından:

Uygulamada vekilin temsil ettiği kimseye ait taşınmazı kendisi için satın alması olaylarına da rastlanmaktadır. Buna "kendisiyle işlem" '(Insichgeschäft, Selbskontrahieren, Selbseintritt=contrat avec soi-même) demek mümkündür. Alman hukukunda böyle bir

93. Vekilin, yalnız satma yetkisi olduğu halde, taşınmazı bă̆ışlaması geçersizdir. Bu konuda yetkili olmadığindan temlik işlemi geçersizdir. Bkz. Y. I. HD. T. 28.5.1975, E. 4999, K. 3961 (Dalamanli/Kazanci/Kazanc1, IV, sh. 67-68). HGK, T. 2.12.1953, E. $1-183$, K. 145 (Velidedeo glu/Esmer, sh. 47-48) Ayn yönde karar için bkz. 4 . HD. T. 21.10.1969, E. 7875, K. 8733 (Karahasan, Borçlar, C.6, sh. 670-671).

94. Tandoğan II, sh. 399; Yavuz, Temsil, sh. 178; Yılmaz, sh. 15.

95. Bkz. 9.12.1929 tarih ve 467 sayıl genelge. Metin için bkz. Esmer, sh. 645.

96. Y. 14. HD.'nin T. 29.11.1977, E. 4734, K. 5904 sayll kararından:"... satma yetkisi satıss vaadinde bulunma yetkisini de kapsar..." (Dalamanly/Kazanc1/Kazancı, IV, sh. 62-63).

97. Velidededoğlu/Esmer, sh, 42-43; Karahasan, Borçlar, C.4, sh. 216. Ayn yazar, Eşya, sh. 366.

98. Kocayusufpaşaoğlu, Vaad, sh. 107. 
olay BGB \& 181 hükmü ile kural olarak yasaklanmıştır" ${ }^{99}$. Gerçekten BGB $\$ 181$ 'de şu hüküm yer almaktadır: "Bir temsilci aksine hareket etmesine izin verilmedikçe, temsil olunan adına bizzat kendisiyle veya bir üçüncüi kimsenin temsilcisi sıfatıyla bir hukukî işlem yapamaz, meğer ki bu hukukî işlem münhasıran bir borcun ifasını teşkil etsin"100.

Türk/İsviçre hukukunda bu konuda bir hüküm mevcut değildir $^{101}$. Ancak, başkasını tevkil için verilen yetki, temsil edilene ait taşınmazın vekil tarafından satın alınması için yeterli değildir. Böyle bir işlemin geçetli olabilmesi için; taşınmaz satımı konusunda verilen vekâlette, müvekkịlin bu yetkiyi vekile açıkça vermiş olması gerekir $^{102}$. İsviçre'de doktrin ve Federal Mahkeme, vekilin kendi kendisiyle sözleşme yapabilmesi için müvekkilin bu konuda vekile. açıkça yetki vermiş olmasını aramaktadırlar. Buna göre, böyle bir sözleşme yapılmasının müvekkil için herhangi bir tehlike yaratmaması gerekir. Başka bir deyişle, müvekkil açısından taşınmazın üçüncí kişi tarafından satın alınması ile vekilin kendisine satın alması arasında bir fark olmamalıdı! ${ }^{103}$. Aynı şartlar Türk hu-

99. Palandt/Heinrichs, Bürgerliches Gesetzbuch, 55. Auf. München 1996, $\$ 181$, Nr. 1 ; Hofstetter, sh. 82. Söz konusu kavramlar ile ilgili tartuşmalar için bkz. Fellmann, Art. 398, Nr. 100 vd; Gautschi, Art. 396, Nr. 49a vd; Hatemi, A./Serozan, HJ Arpacı, R. Borçlar Hukuku Ôzel Bölüm, İstanbul 1992 sh. 484 vd. Bu yasak, Alman kanun koyucusunun söz konusu kuruma karş̧ duyduğu endişeden kaynakJanmakta olup, böyle bir yasağın ihlâlinin yaptırımı iptaldir. Bkz. Palandt/Heinirichs, \$181, Nr. 15; BGHZ, 65, 125. Aksi fukir için bkz Esener, Temsil, sh. 159. Cünkü, böyle hallerde genellikle vekil ile muivekkii arasında bir menfaat çatışması söz konusudur. Bkz. Hofstetter, sh. 82, BGE 89 II 326. Alman kanun koyucusunun amacı, taraflar arasındaki menfaat catışmasın önlemektir. Gerçekten 0 , böyle bir işlernin müvekkilin menfaatlerini ihlấ edeceği karinesinden hareket etmiştir. Bkz. Esener Temsil, sh. 159.

100. Bu konuda geniş bilgi için bkz: Esener, Temsil, sh. 158; Hatemi/Serozan/Arpact, Borçlar, sh. 484 vd. Böyle bir yasağın ikj istisnası vandır: Birinci istisna, temsit belgesinde böyle bir yetkinin açıça yer almıs olması, ikincisi ise, böyle bir işlemin bir boncun ifasını oluşturmasıđır. Buntunla birlikte, doktrinde, mutivekkilin, vekilin taşınmazı kendịi için almasına ses çıkarmaması da üçüncü istisna olarak kabul edilmektedir. Bkz. von Tuhr/Peter, sh. 364, not. 54a; Palandt/Heinrichs, \$181, Nr. 16 vd; Esener, Temsil, sh. 160 vd. Böyle bir halde müvekkilin, bu hukukî işleme icazet vererek geçerlik kazandirmaşı söz konusudur. von Tuhr/Peter, sh. 365 ; Esener, Temsil, sh. 171; Oguzman, M.K $/ O ̈ z, T$. Borçlar Hukuku Genel Hüküumler İstanbul $1995 \mathrm{sh}$. 167.

101. Ayni sonuc, Fransız hukuku bakımından da geçerlidir. Doktrin ise, böyle bir kurumu, hukuk tekniğ bakımından kabul etmektedir. Bkz. Esener, Temsil, sh. 161 vd.

102. Esmer, sh. 733; Tekinay/Akman/Burcuog/u/Altop, sh. 238-239; Eren, I sh. 471; Inan, sh. 130; Esener, Turhan, Borçlar Hukuku, C. I, Ankara 1969, sh. 284-285.

103. von Tuhr/Peter, sh. 364; Gautschi, Art. 396, Nr. 49b; Yıldı, sh. 42; Gauch, PJ Schluep, W.; Schweizerisches Obligationenrecht Algemeiner Teil, 6. Auf. Zürich 1995, Nr. 1439; Guhl/Merz/Koller, sh. 148; Esener, Temsil, sh. 155. BGE 89 II 326, 95 II 621. 
kukunda da geçerlidir ${ }^{104}$ Ayrıca, vekâletnamede açıklama yoksa, tespit edilen bedelin ödenmesi ve vekâletnamedeki diğer şartlara uyulması ve yerine getirilmiş olması gerekir ${ }^{105}$. Müvekkil ile vekil arasında menfaat ihlâlinin olduğu bir yerde, vekil bu konuda özel yetkisi bulunmadıkça genel bir yetkiye sahip olsa bile, kendi kendisiyle işlem yapamaz.

\section{5) Vekâletin düzenlenmesi açısından:}

\section{a) Kü̧̈üklere ait vekâletnameler:}

Veli, velayeti altındaki küçüğe ait taşınmazı satmak hususundaki hak ve yetkilerini, tayin edeceği bir vekil aracilığ ile kullanabilir. Bu konuda herhangi bir sınırlama mevcut değildir. Bunun için vekilin, vekâleten taşınmaz satımı sözleşmesini yaptığı anda kủ̧̧̧ügün rüştüne ermiş olmaması gerekir ${ }^{\text {tot }}$.

\section{b) Silah altundakilere ait vekâletnameler:}

1111 sayılı Askerlik Kanunu m.39 ve m.61'değiştiren 4152 sayulı Kanunda askerde bulunan erbaş ve erlerin temsili hususunda özel hükümler getirilmiştir ${ }^{107}$. Söz konusu Kanun'a göre, vekâletname veya onaylamaya yetkili kılınan görevliler, taşınmaz satımı için de vekâlet düzenleyebilir ${ }^{108}$. Böyle bir vekâletname, silah altında bulunan kimsenin terhisinden itibaren iki ay süre ile geçerlidir ${ }^{109}$.

104. Esener, Temsil, sh. 167; Saymen F. Hakkı; Bir Tek Şahșın Akdin İki Tarafını Temsil Edebilmesi Meselesi, Ebul Ul'a Mardin'e Amagan, İstanbul 1940, sh. 1113; Eren, I sh. 535; Esener, Borçlar, sh. 285; Tekinay/Akman/Burcuoğlu/Altop, sh. 167; Öuzman $/ 0 \mathrm{z}, \mathrm{sh} .168$.

105. Esener, Temsil, sh. 155; Saymen, sh. 1114 vd; Karahasan, sh. 369; Sungurbey, Ismet; Vekilin, Vekillik Veren İçin Satın Aldı̆̆ı Taşınmazı Vekillik Verene Geçirme Borcu Ustione, Medeni Hukuk Eleştirileri, Istanbul 1963, sh. 148 vd. Aynca bkz. YİBK. T. 7.10.1953, E. 8, K.7.

106. Esmer, sh. 734-735; BGE 84 II 157; 81 II 213.

107. Düstur, Üçüncil Tertip, C. 23, sh.91.1111 sayılı Kanun m. 61 hükmü şöyledir: "Hazarda veya seferde silah altına çağrılan muvazzaf veya ihtiyat erbaş ve erler resmî veya hususî her türlü işlerinde kendilerini temsil etmek üzere ditledikleri bir şahsı ikinci fikrada yazılı húkilmler dairesinde tanzim edilecek bir vekâletname ile de tevkil edebilirler......."

Birinci fıkrada yazılı vekâletnameler askerliğe daveti müteakip ve kıtaya iltihaktan önce noterler, noter bulunmayan yerlerde suth hâkimleri veya vilayet veya kaza jandarma kumandanlan ile askerlik şubeleri rejsleri ve kıtaya iltihaktan sonrada askeri hâkimler, bölük kumandanjarı veya bulundukları mülessese amirleri tarafından tanzim ve tasdik olunur... Bu maddeye tevfikan tanzim kilınan vekâletnamelerin hìkümleri erbas ve erlerin terhislerinden iki ay sonrasına kadar devam edir."

108. Esmer, sh. 678-679.

109. Geniş bilgi için bkz. Esmer, sh. 735 . 
c) Yabancı ülkelerde bulunan Türk vatandaslart ve yabancılarin verecekleri vekâletler:

aa) Yabancı ülkelerdeki Türklerin verecekleri vekâletnameler:

Türk vatandaşı olup da, yurt dışında bulunanların verecekleri vekâletnamelerin yetkili Türk makamları (konsoloslukları) tarafından düzenlenmesi veya onaylanması gerekir ${ }^{\text {'to }}$. Uygulama da bu yöndedir. Ancak, bu gibi kimseletin bulundukları ülkede noterlik görevini gören makamlara da vekâletname düzenlettirmeleri mümkündür "II' Böyle bir halde NK.m. 195'e göre, kural olarak, yabancı ülkede usulüne uygun olarak düzenlenen vekâletin altındaki, o ülkenin yetkili merciinin imza ve mührünün, Türk konsolosu tarafından dà onaylanması gerekir ${ }^{12}$.

\section{bb) Yabancilara ait vekâletnameler}

Türkiye'de taşınmaz satın almak isteyen yabancı uyruklu kimseler ülkemizde bulunmuyorlarsa taşınmaz satımı için verecekleri velâketnamelerin, bulunduklan ülke mevzuatına göre, bu görevi ifa eden merciiler tarafından düzenlenmesi gerekir. Yabancı, kendi ülkesinden başka bir ülkede bulunuyorsa, bulundugu tilkenin mevzuatına uygun hareket edebileceği gibi, vekâletnameyi düzenleyen görevlinin bu iş için kanunî sıfat ve yetkisinin mevcut olduğunu ve vekâletin yetkililer tarafından düzenlenmiş bulunduğunun, o ülkedeki Türk elçilik veya konsoloslukları tarafından onaylanması gere$\mathrm{kir}^{13}$.

\section{Taşınmaz Satımında Vekâletin Sona Ermesi:}

Taşımmaż satımı için verilen vekâlet, çeşitli sebeplerle sona erebilir. Her şeyden önce, vekâletname ile verilen temsil yetkisi, sadece belirli bir işlem için verilmişse, söz konusu işlemin yapılması ile vekâlet sona erer. Aynı şekilde vekâletin belirli bir süre ile sınırlandırılması halinde verilen yetki, söz konusu sürenin bitiminde sona erer.

110. NK.m.191. Bu konuda geniş bilgi için bkz. Ulukapı/Atalı, sh. 152.

111. Vural, sh. 200-201; Esmer, sh. 736 .

112. Bu konuda geniş bilgi için bkz. Ulukapv/Atalı, sh. 154; Esmer, sh. 736; Tanju, Fahrettin; Tapu ile lìgili Vekâletnaneler, TNBHD. S.95 (1997), sh. 26.

113. Esmer, sh. 735; Ulukapv/Atalı, sh. 152-153. 
Vekâlet, azil veya istifa ile de sona erebilir. Çünkü vekâlet karşılıklı güvene dayanan bir sözleşmedir. Bir tarafın, karşı tarafa olan güven duygusunun yitirmesi ile, bu ilişkiye bir son vermesi mümkündür. Uygulamada en çok başvurulan yol da budur ${ }^{1 / 4}$.

BK.m.397/I'e göre, aksi sözleşmeden veya işin niteliğinden anlaşılmadıkça vekâlet, gerek vekilin, gerek müvekkilin ölümỉ ile sona erer ${ }^{\prime \prime s}$. Keza, ehliyetsizlik ve iflâs da vekâletin sona erme sebeplerindedir ${ }^{116}$.

\section{SONUÇ}

Taşınmaz satımının, bizzat malik tarafından değilde, tayin edeceği bir vekil tarafından yapılması mümkündür. Vekilin böyle bir yetkjyi kullanabilmesi için BK.m.388/III'na göre, özel bir yetkisinin bulunması gerekir. Bu yetki verilirken taşınmazın yeri ve nitelikleri açıkça belirtilmelidir. Bu vekâletnamede birden çok taşınmaz hakkında yapılacak ise, her bir işlem ayn ayn belirtilmelidir.

Vekilin, taşınmaz maliki adına satı̧ yapması için verilen vekâletin şekli konusunda doktrin ve uygulamada farklı cevaplar verilmiştir. Kanımızca taşınmaz satımı için yapılan vekâlet sözleşmesi geçerlik açısından hiçbir şekle tâbi değildir. Buna karşıllı, böyle bir vekâletin isbat açısından tapu memurunda - o kimsenin vekil olduğuna dair yeterli kanaat getirecek şekilde olması gerekir.

Doktrinde tartışmalara neden olan NK.m. 89 , Medeni Kanun ve Borçlar Kanunu'ndaki şekle ilişkin kuralları deģş̧tirmemiştir. Bu konudaki tartışmaları sona erdirmek ve uygulamada birliğ sağlamak için yeni bir kanun hükmüne ihtiyaç bulunmaktadır. Fakat, kanun değişikliği yapılıncaya kadar Yargıtay kabul edeceği bir içtihatla bu konudaki tartışmaları sone erdirebilir. Bunu için Yargıtay'in miras taksim sözleşmesi açısından getirdiği açıklı̆̆ı, taşınmaz satımı için verilen vekâlet için de getirmesinde fayda vardır.

114. Bkz. Gürsoy, Kemal; Vekâlet Akdinin Ölüm Nedeniyle Sona Ermesi ve Sonuçlan, Temsil ve Vekâlete Ilisskin Sorunlar Sempozyumu, tstanbul 1977, sh. 1 vo.

115. Hofstetter, sh. 57 vd; Tandoğan II, sh. 669 vd. YIBK. T. 22.2.1941, E. 1938/20, K. 1941/87: “... Vekil edenin ölimüunden sonra dahi taşınmaz malının başkașına satışına ferağının verilmesine dair vekâlet ilişkisinin süregeleceł̣i taraflar arasında kararlaştırılmışsa, ölömden sonra da vekilin yetkileri süregelir. Ancak, miras bırakanın olümiliyle görevden alma (azil) hakkı mirasçılara geçtiģinden, bunlar vekili jşten uzaklaştırabilirler..." Bkz. Yargıtay lçtihadł Birleştime Kararları, C. 1, Ankara 1978 , sh. 542-561.

116. Aral, sh. 234. 